\title{
Hare-Lip Surgery in the History of Traditional Chinese Medicine
}

\author{
KAN-WEN MA*
}

There have been a few articles published in Chinese and English on hare-lip surgery in the history of traditional Chinese medicine. They are brief and some of them are inaccurate, although two recent English articles on this subject have presented an adequate picture on some aspects. ${ }^{1}$ This article offers unreported information and evidence of both congenital and traumatic hare-lip surgery in the history of traditional Chinese medicine and also clarifies and corrects some of the facts and mistakes that have appeared in works previously published either in Chinese or English.

\section{Descriptions of Hare-Lip and its Treatment in Non-Medical Literature}

The earliest record of hare-lip in ancient China with an imaginary explanation for its cause is found in 淮南子 Huainan $Z i$, a book attributed to Liu An (179-122 BC). It says: "A pregnant woman who saw a hare as a result gave birth to a baby with a 缺店 'Que Chun" "2 (Figure 1). Here, "Que" literally means imperfect, defective, gap, or cleft, and "Chun", lip. So, "Que Chun" means an imperfect, defective, gapped or cleft lip.

The first record of the practice of hare-lip surgery in China is not later than the fourth century AD. It occurs in the story of a man called 魏永之 Wei Yongzhi described in the fin Shu, a book on the history of the Jin dynasty (AD 265-420), which presents a series of biographies of historical figures compiled by a group of twenty-one scholars and officials headed by Fang Xuanling between 644 and 646. The following passage relates to hare-lip surgery:

* Professor . 馬堪湿 Kan-Wen Ma, The Wellcome Trust Centre for the History of Medicine at UCL, 24 Eversholt Street, London NW1 1AD, UK.

I would like to express my sincere thanks to the Wellcome Trust and the Wellcome Institute for the History of Medicine, where I have been working in recent years, which have provided me with many facilities for my research, to Dr Nigel Allan for his kind reading of and valuable comments on this paper, to Professor $\mathrm{Xu} \mathrm{Fu}-$ Song for his explanations of some of the terms on hare-lip operation, to the two anonymous referees for their constructive comments on this paper, to the Medical Photographic Library of the Wellcome Trust, and to Mr Chris Carter for his assistance in producing the illustrations.

\footnotetext{
${ }^{1}$ Khoo Boo-Chai, 'An ancient Chinese text on a cleft-lip', Plast. Reconst. Surg., 1966, 38 (2): 89-91; J Vrebos, 'Harelip surgery in ancient China: further investigations', ibid., 1992, 89 (1): $147-50$.

${ }^{2}$ Huainan $Z i$, 'Shuo Shan Xun' 16, in Sibu Congkan, $\mathrm{Zi} \mathrm{Bu}$, photomechanical printing, Shanghai, Han Fen Lou, 1824, p. 16. Throughout this article, all the translations are mine.
} 


\section{Kan-Wen Ma}

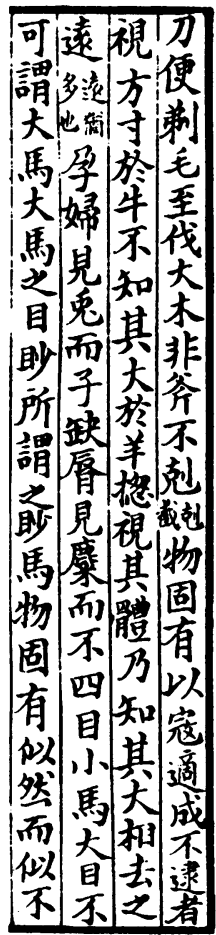

Figure 1: The earliest record of cleft-lip ("Que Chun") with an imaginary explanation for its cause relating to the hare. From Huainan $Z i$, a book attributed to Liu An (179-122 BC) (see note 2).

Wei Yongzhi, also called Wei Changdao, a native of Rencheng, ${ }^{3}$ who came of a poor family, while engaged in farm work, studied with tireless zeal. Born with a 兔铁 “Tu Que" (harelip), he was told by an expert physiognomist that he should be wealthy and noble. When he was eighteen, he heard that a "ming yi" (famous medical man) 4 under 般仲埃 Yin Zhongkan, the Governor of Jingzhou, ${ }^{5}$ could heal it. Although he was too poor to undertake such a trip, he said to his family: "Being deformed and ugly, what are my possibilities if I continue to live like this?" He then went his way west to Yin Zhongkan's place, taking with him several $\mathrm{Hu}$ of rice. ${ }^{6}$ Having arrived at Yin's mansion he called at the entrance and was received. Yin Zhongkan was pleased to know his good intention, and summoned the medical man to see him. "The hare-lip can be cut and mended," said the doctor, "but, you are allowed to eat only porridge and should not speak or smile for a hundred days." "Well, I will have it healed, " replied Wei Yongzhi, "even if I am not allowed to speak for half my lifetime, for even then

\footnotetext{
${ }^{3}$ Rencheng, now in Qufu county, Shandong province.

4 "Ming Yi", "Ming" means famous or wellknown, "Yi" means man of medicine, or man who heals people's illnesses. In ancient China, "Yi" was a general term for men who practised medicine, either internal, external, or other therapeutic measures.
} 


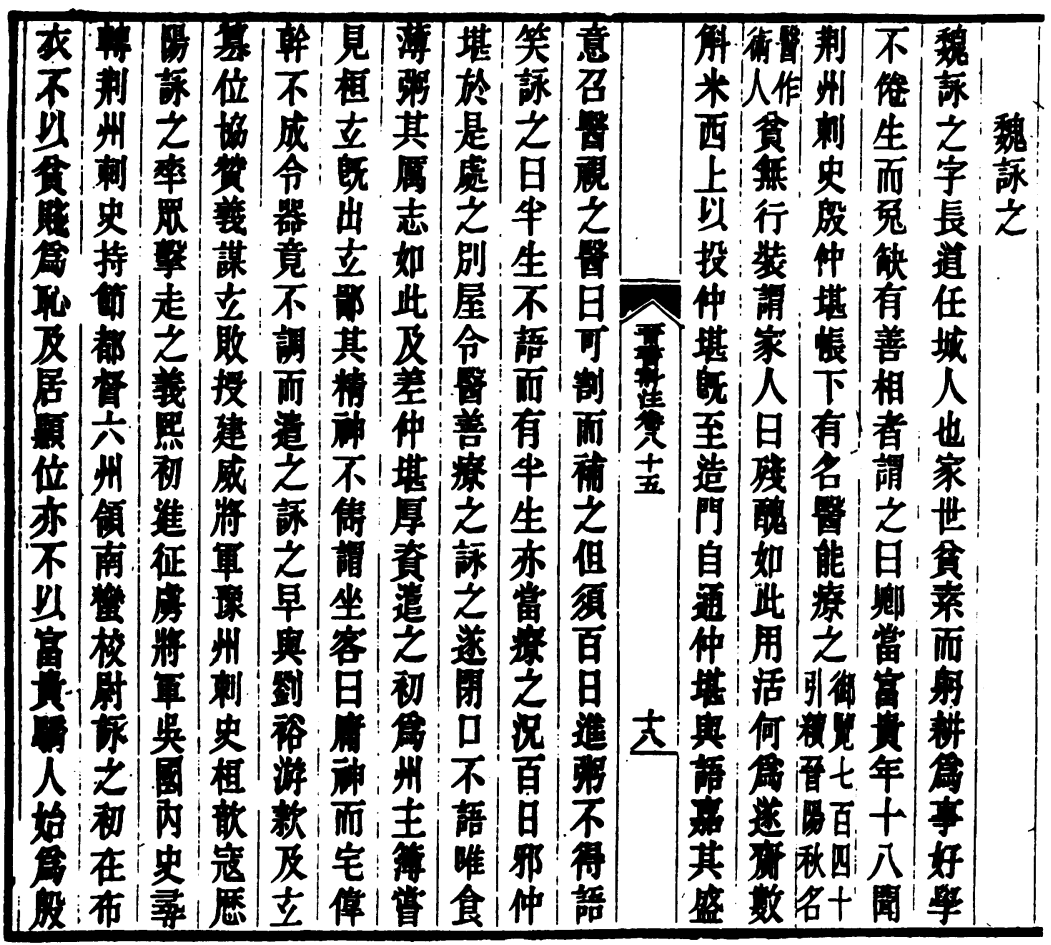

Figure 2: The earliest record of hare-lip surgery on a man called Wei Yongzhi (fourth century AD). From Jin Shu (History of the Jin dynasty), by Fang Xuanling et al. between 644 and 646 AD (see note 7).

I will still have the other half of my lifetime. Why should I care about one hundred days?" Yin Zhongkan then arranged for him to stay in a separate room and bade the doctor perform the operation with care. Following the doctor's instructions, Wei Yongzhi closed his mouth without uttering a word, and ate only thin porridge. His hare-lip was healed as a result of his strong determination. He was then given a good sum of money by Yin Zhongkan for his trip home. ${ }^{7}$ (Figure 2.)

In this story, we find not only the first recording of hare-lip surgery, but also the first mention of the term "Tu Que" (hare-lip). "Tu" means hare or rabbit, and "Que", gap, cleft, or defect.

According to the Jin Shu, Wei Yongzhi embarked on an official career soon after his hare-lip was repaired. In the year of Yixi (AD 405) during the reign of Emperor An of the Jin dynasty (405-418) he was appointed Governor of Jingzhou, the same position that his host Yin Zhongkan had previously held. ${ }^{8}$ As for Yin Zhongkan,

\footnotetext{
${ }^{7}$ Fang Xuanling et al., Jin Shu, vol. 85, 'Le Zhuan' p. 55, reprint, Beijing, Zhonghua Shuju, 1974 , vol. 7 , pp. 2217-18. This story is also recorded in volume 85 of Cefu Yuangui, a thousand volume work dealing with ancient
}

\author{
history down to the Five Dynasties (AD 907-1279) \\ compiled by Wang Qin-Ruo et al., between 1005 \\ and 1013. \\ ${ }^{8}$ Ibid., Fang Xuanling et al., p. 2218.
}




\section{Kan-Wen Ma}

we know that he was a native of Chenjun, now Huaiyang county, Henan province, in Central China. Born into a family of several generations of high officials, he was well versed in literature, and was well-known for his filial piety and his generosity in helping people. It is recorded that, when his father was ill, he attended his bedside with medicines day and night without taking any sleep. In order to cure his father's illness he studied medicine and compiled a medical work entitled Yin Jingzhou Yaofang (Essential prescriptions of Yin Jingzhou), which, unfortunately, has been lost. ${ }^{9}$ After holding several official positions, he became Governor of Jingzhou, an area of strategic military importance. It would appear, therefore, that the operation that Wei Yongzhi underwent was carried out by a surgeon attached to Yin Zhongkan's army. This surgeon, however, was misrepresented as a pupil of Yin Zhongkan by some early authors. ${ }^{10}$

As for the date of the operation on Wei Yongzhi's hare-lip, Khoo Boo-Chai placed it some time before the end of the fourth century, i.e., circa AD $390 ;{ }^{11} \mathrm{~J}$ Vrebos considered it to have taken place " $\pm 390 " ;{ }^{12}$ Guo Aichun set it at $392 .{ }^{13}$ A more precise dating may however be drawn from biographical details relating to Wei Yongzhi and Yin Zhongkan. According to the Jin Shu, in the seventeenth year (392) of Taiyuan during the reign of Emperor Xiaowu (373-395), Yin Zhongkan was appointed Governor of Jingzhou, so obviously Wei Yongzhi's operation could not have occurred before this appointment, i.e. before the year 392. From 396 until his death in 399, Yin Zhongkan was heavily involved in an army rebellion, and was forced to commit suicide after the failure of a military coup. ${ }^{14}$ Thus, the date of the operation for Wei Yongzhi's hare-lip would most probably have taken place between 392 and 395, when Yin Zhongkan was already Governor of Jingzhou and not yet very involved in the conflict between the powerful families of the Eastern Jin dynasty, since it would have been difficult for Yin Zhongkan to receive Wei Yongzhi and to arrange the operation during the period of his many military activities.

Another record of hare-lip surgery relates to a man named $万 千$ Fang Gan (d. c. 888). This account was first mentioned in a book entitled 整戒保 Jianjie Lu (Records

\footnotetext{
${ }^{9}$ This book by Yin Zhongkan was first recorded in the $Q i L u$, a bibliographical work compiled by Ruan Xiaoxu of the Liang dynasty (sixth century $\mathrm{AD}$ ), which was subsequently lost, and its main contents were later included in the Sui Shu (History of the Sui dynasty) compiled by Wei Zheng et al., in AD 636. The Yin Jingzhou Yaofang is listed in Sui Shu, vol. 34, 'Jingji Zhi' 3, reprinted and annotated edition, Beijing, Zhonghua Shuju, 1962, p. 1042.

${ }^{10}$ Wang and Wu, History of Chinese Medicine, 2nd ed., Shanghai, National Quarantine Service, 1936, p. 233. p. 91 .

"Khoo Boo-Chai, op. cit., note 1 above,

${ }^{12}$ Vrebos, op. cit., note 1 above, p. 149.
}

\footnotetext{
${ }^{13}$ Guo Aichun, Zhongguo yishi nianbiao (Chronological table of the history of Chinese medicine), Haerbin, Heilongiiang Renmin Chubanshe, 1984, p. 22. Citing the Taiping Yulian (The peaceful imperial readings, vol. 740), which gives a brief description of Fang Gan's story but no definite date of the operation, Guo Aichun set the date at $\mathrm{AD} 392$ without giving any explanation.

${ }^{14}$ Fang Xuanling et al., op. cit., note 7 above, vol. 84, 'Lie Zhuan' 54 'Yin Zhongkan', pp. 2192-9. See also Tian Yuqing, Dongjin Menfa Zhengzhi (Politics of the families of power of the East Jin Dynasty), Beijing, Peking University Press, 1989, pp. 275-8.
} 


\section{Hare-Lip Surgery in the History of Traditional Chinese Medicine}

of warnings) written by 何光速 He Guangyuan, ${ }^{15}$ who probably lived in the middle of the tenth century. The following is the section relating to this story:

Fang Gan was a scholar [who] ... whenever he met someone, would bow three times, saying that he was following the ethical code of courtesy. For this reason he was nicknamed "Fang Sanbai" (Three Bows Fang) by his acquaintances. He was also called "Fang Shisi Lang" (the fourteenth son of the Fang family). A hare-lipped man, he sat for more than ten imperial examinations but failed to be awarded the title of successful candidate in the highest imperial examination because the authorities thought that, although he had ability, it would not be feasible to award this title to a man with a hare-lip, since people both at home and abroad would say that the Chinese nation was lacking scholars. Realizing the opinion of the authorities, he returned to Jinghu, ${ }^{16}$ where over ten years later he met a medical man and had his harelip repaired, but by then he was already an old man ... He never again left Jinghu, and was nicknamed "Buchun Xiansheng" (Mr Lip Mended) by the people there. ${ }^{17}$ (Figure 3.)

The Jianjie $L u$ records events relating to the emperors and their subjects from the Tang dynasty (AD 618-907) to the Wu Dai (Five Dynasties, 907-960) by which the author sought to admonish the country. The story of Fang Gan comes under the heading of ' $\mathrm{Qu}$ Mingru' (Injustice to noted scholars) and records that Fang Gan was posthumously recognized as a successful candidate in the highest imperial examination. This was the result of a petition presented to the Emperor by a court minister named Zhang Wenwei and others in the late Tang dynasty, requesting that the title of successful candidate be granted to the "solitary souls" of fifteen noted scholars, who had been unjustly treated and not recognized as successful candidates in the highest imperial examination during their lifetime. Fang Gan was one of the fifteen. ${ }^{18} \mathrm{~A}$ similar request for posthumous recognition of Fang Gan is also found in 唐摭言 Tang Zhiyan (Notes on the Tang Dynasty), by 王定保 Wang Dingbao, ${ }^{19}$ a high-ranking official (ninth to tenth centuries), who recorded many events and activities relating to the imperial examination systems of the Tang dynasty and of the Five Dynasties. It is stated in this book that a memorial ${ }^{20}$ was presented by Wei Zhuang ${ }^{21}$ to the Emperor requesting permission to confer posthumously the title of

\footnotetext{
${ }^{15} \mathrm{He}$ Guangyuan, also called He Huifu, a native of Dong Hai, now in Jiangsu province. He acted in a military capacity between 938 and 965 , but was also a literary man, interested in ancient studies. His work, Jianjie $L u$, consists of 10 volumes.

${ }^{16}$ Jinghu, Lake Jing, now in Guiji, Shaoxing, Zhejiang province.

${ }^{17} \mathrm{He}$ Guangyuan, Jianjie $L u$, 'Qu Mingru', vol. 8, pp. 8-11, in Qinding Siku Quanshu, Zi Bu 12, Xiaoshuojia Lie 1, photomechanical printing, Shanghai, Guji Chubanshe, 1987, pp. 912-14.

${ }^{18}$ Ibid., p. 8.

${ }^{19}$ Wang Dingbao, a native of Nanmao, now in Jiangxi province. Born in the year AD 870, he became a successful candidate in the highest imperial examination in the third year of Guang Hua (900). He was a high official during the South Han dynasty (907-1025), and his book,
}

which consists of 15 volumes, was compiled after 954. See 'Ti Yao', Tang Zhiyan, included in Qinding Siku Quanshu, op. cit., note 17 above, pp. 695-6.

${ }^{20}$ See Wang Ding-Bao, 'Wei Zhuang Zhouqing Zuizeng Bujidiren Jindaizhe', Tang Zhiyan, vol. 10, pp. 16-20, included in Qinding Siku Quanshu, op. cit., note 17 above, pp. 773-5.

${ }^{21}$ Wei Zhuang (c. 836-930), also called Wei Duanji, a native of Changan, Duling, now Changan county, Shanxi province. A successful candidate in the highest imperial examination between the years 894 and 898 (Qianning) during the reign of Emperor Tang Zhaozong, he later became a high official to the Qian Shu dynasty (907-925). He was also a noted poet. See Ci Hai, compiled by Cihai Bianji Weiyuan Hui, Shanghai, Cishu Chubanshe, 1979, the reduced format ed., 1980, p. 1234. 

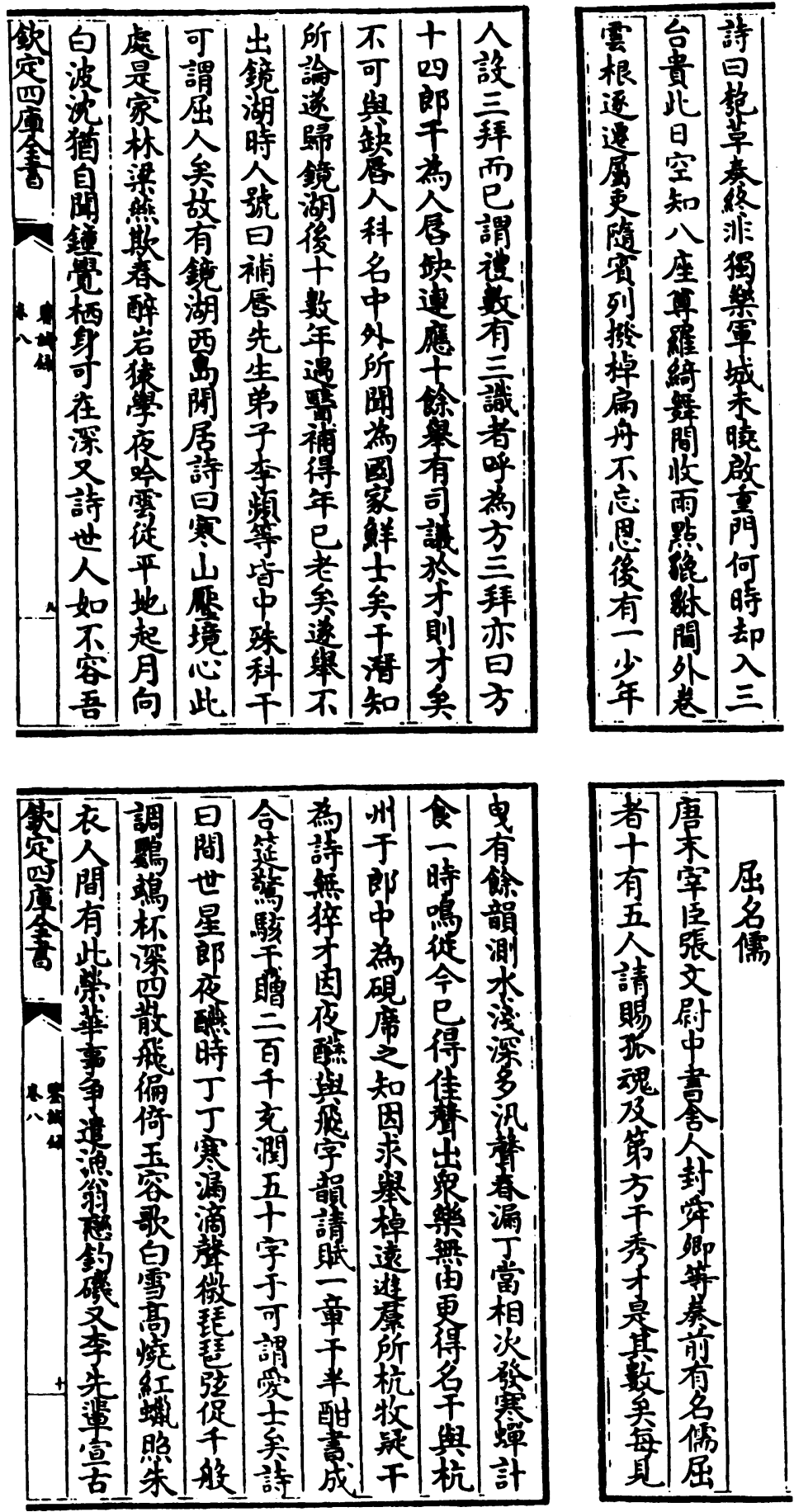


\section{Hare-Lip Surgery in the History of Traditional Chinese Medicine}

successful candidate of the highest imperial examination to those who, for various reasons, had been unable to obtain such a title, and Fang Gan was among them.

Fang Gan's story is mentioned in a number of works dealing with poetry and other related writings between the tenth and seventeenth centuries. ${ }^{22}$ According to many sources, we know that Fang Gan was also called Fang Xiongfei. He was a native of Xin Ding, now Jian De county, in Zhejiang province. ${ }^{23}$ His reputation for composing poems of eight lines was so high that it was said no other poet between the years 88 and 888 could surpass him. He had many admirers and his poems were edited by his pupil Yang Yan. ${ }^{24}$

Hitherto unknown evidence for the date of Fang Gan's operation is found in a poem about him by 徐天祐 $\mathrm{Xu}$ Tianyou, ${ }^{25}$ a scholar and a high-ranking official of the Song dynasty. The following is a free translation of the poem:

\section{"Fang Gan Island"}

Located in the Jian Lake, also called Sun village

The life-long sorrow (of Fang Gan) shared with the white gulls. In the hut amongst the clouds there is a volume of poems written by the gifted scholar-poet who lived as a recluse. Looking

Figure 3: (opposite) Record of hare-lip surgery on a poet called Fang Gan (d. c. 888). From Jianji $L u$ (Records of warnings) written by He Guangyuan, probably in the middle of the tenth century (see note 17).

\footnotetext{
${ }^{22}$ See Tangshi Jishi (Chronicles of the Tang dynasty poetry) by Ji Yougong, Shanghai, reprinted by Beiye Shanfang, 1944, vol. 63, p. 972. Ji Yougong was also called Ji Mingfu. A scholar and an official, he probably wrote this work in the early part of the twelfth century; Houcun Shihua (Houcun's notes on poets and poetry) by Liu Kezhung in the middle thirteenth century, included in the Sibu Cungkan, Jibu, reprinted by Shanghai Commercial Press, 1936, vol. 184 , p. 13. Liu Kezhuang (1186-1269) was a high-ranking court official and poet of the Southern Song dynasty. The work was originally included in the Houcun Xianshen Daquanji (Complete works of Mr Houcun), published during the South Song dynasty (1127-1279). It has been considered a reliable source for the study of Chinese poetry, and has been repeatedly quoted in many related works; Liuting Shihua (Liuting's notes on poets and poetry) by Song Changbai in 1704, which is included in Zhongguo Wenxue Zhenben Cungshu, 1, the second category, reprinted by Shanghai Zaizhi Gongsi, 1935, vol. 1, pp. 12-13; Tang Caizi Zhuan (Gifted scholars of the Tang dynasty) by Xin Wenfang, first appeared in the Yuan dynasty in 10 volumes and was subsequently lost, and was re-edited by $\mathrm{Lu}$ Zhiyoun in the Qing dynasty based on the
}

material preserved in Japan. The present edition was collated and annotated by Sun Yinggui, and published in Beijing by Zhongguo Shenhui Kexue Chubanshe, 1991, pp. 694-700; Junzhai Dushu Zhi (Junzhai's notes of readings) by Cao Gongwu in the twelfth century, and was collated by Sun Men, Shanghai, reprinted by Guji Chubanshe, 1990, pp. 936-7; Shangyou Lu (A biographical dictionary classified under rhymes), by Liao Yungxian in 1666, vol. 10, p. 44. This work was edited by Zhang Bozung, and re-edited by Zhang Renzheng et al.

${ }^{23}$ Some sources say that his native place was $\mathrm{Xinan}$, or Tung $\mathrm{Lu}$, or $\mathrm{Xi}$. They are in fact the same place accorded different names during different dynasties, for all these places belonged to Muzhou, an administrative division originally established by the Sui dynasty in the year 603 .

${ }^{24}$ See Xuanying Ji, 'Tiyao', in Qinding Siku Quanshu, 'Jibu', op. cit., note 17 above, pp. 42-5, 83-4.

${ }^{25} \mathrm{Xu}$ Tianyou, also called Xu Shouzhi, a native of Shaoxing, was a successful candidate in the highest imperial examination and became an official. After his resignation in 1275, he devoted himself to study and attracted many scholars from various places to discuss literature and art. 


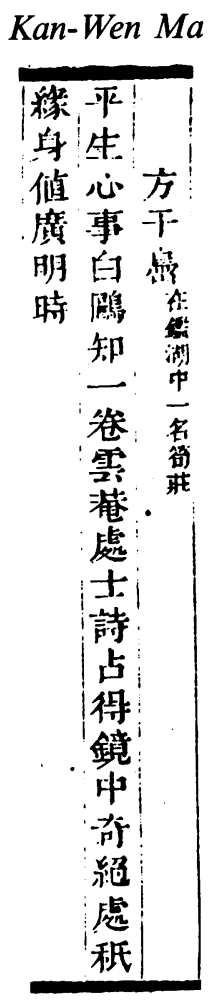

Figure 4: A poem by Xu Tianyou (thirteenth century) indicating the date of the hare-lip operation on Fang Gan. From Songshi Jishi (Notes on poems of the Song dynasty) by Li E (1692-1752) (see note 26).

in the mirror he marvels at his wonderfully repaired hare-lip. It was remarkable because it happened during the year of Guan Ming. ${ }^{26}$ (Figure 4.)

Guan Ming is the name for $\mathrm{AD} 880$, a year during the reign of the Emperor Xi of the Tang dynasty. Thus we know the date of the operation that Fang Gan underwent for his hare-lip. We can gather from this poem that the operation was highly successful, although Fang Gan probably died four or five years later. ${ }^{27}$

Some mistakes about Fang Gan's hare-lip operation have appeared in works

${ }^{26}$ This poem is included in Liuting Shihua. In this poem the place where Fang Gan lived as a recluse is called Fang Gan Dao (Fang Gan's Island). See Song Changbai, note 22 above. See also Songshi Jishi (Notes on poems of the Song dynasty) by Li E (1692-1752), 1746 , vol. 66 , p. 5.

${ }^{27}$ There are different opinions on the dates of Fang Gan's birth and death: (1) The biography of Fang Gan written by Sun He says that he died between the years of Guang Qi (885-887) and
Wen De (888); Houcun Shihua, by Liu Kezhuan, supports this view; (2) Tang Caizi Zhuan claims that he died at the end of the period of Xian Tong during the reign of the Emperor Yi Zong (860-870), i.e. about 870; (3) Tangshi Dacidian (Comprehensive dictionary of the Tang poems), edited by Zhou Xungchu, Jiangsu Guji Chubanshe, 1990, gives his death as " 885 ?". The first date, i.e. $885-887$, is probably the most likely, since he was already an old man when he had his hare-lip mended in 880 . 


\section{Hare-Lip Surgery in the History of Traditional Chinese Medicine}

published in English, in which Fang Gan is misrepresented as the operator. ${ }^{28}$ More misleading mistakes appeared in some works published in Chinese. In one article, Fang Gan's attendance at more than ten imperial examinations was interpreted to mean that he himself had successfully carried out over ten surgical operations on the hare-lip; in other works by the same author, although Fang Gan is no longer mistaken as the operator, the unknown surgeon who mended Fang Gan's lip is wrongly said to have carried out ten successful hare-lip operations. Clearly Fang Gan's ten times fruitless attempts at the examinations were again misrepresented. ${ }^{29}$

Further records of hare-lip surgery are included in some district annals in China. In the Yiyang Xianzhi (Annals of Yiyang county), a man called 洪清 Hong Tao, a native of Yiyang, now in Jiangxi province, was described as an expert in the treatment of hare-lip. Hong Tao began his career as a Confucian scholar and later studied medicine and became an Assistant Imperial Physician, serving as a physician in the army during an expedition to Jiaozhi, in the north of Vietnam. Being knowledgeable in medicine, he was appointed physician to Prince Rong Zhuang, Zhu Youshu, the thirteenth son of the Chenghua Emperor of the Ming dynasty, Zhu Jianshen, who reigned from 1465 to 1486 . It is recorded that the Prince suffered from a hare-lip, which was cured with medicines prescribed by Hong Tao. The result was so successful that it appeared as a normal, natural lip. Hong Tao was then called "Mr LipMender" 30 (Figure 5). Although the dates of Hong Tao's birth and death are unknown, the fact that he served as a physician to Prince Rong Zhuang, Zhu Jianshen, suggests that he must have practised in the middle of the sixteenth century.

The Jiangning Fuzhi (Annals of Jiangning Prefecture) describes a man called 吉人杰 Ji Renjie, who was skilful in hare-lip surgery and had practised for over fifty years. $\mathrm{He}$ was the grandson of Ji Zhaolai, a noted local doctor who was an expert in treating external diseases in Jiangning, Jiangsu province. According to these annals, Ji Renjie had a wonderful remedy that could mend the gap of a defective lip in seven days so effectively that no scar could be detected. He was known to have practised this art for over fifty years. ${ }^{31}$

The story of the introduction of hare-lip surgery from China into Japan is also of interest. A surviving account tells of a Japanese man, 高告德明 Tokumei Takamine (1653-1714), born in Ryukyu, who was brought to China at the age of eleven and

\footnotetext{
${ }^{28}$ Quoting the Shangyou $\mathrm{Lu}$, Wong and Wu misrepresented Fang Gan as the surgeon who "was so proficient in this that he was designated as 'the doctor of lips' repair' ", op. cit., note 10 above; W R Morse in Chinese Medicine (New York, Hoeber, 1934, p. 129) made the same assertion without giving any reference. This description has proved to be misleading as it was quoted by other authors such as Blair O Rogers in 'Hare-lip repair in colonial America', Plas. Reconst. Surg., 1964, 31 (2): 146. This has also been pointed out by Dr Vrebos, see note 1 above.

${ }^{29}$ See Li Jingwei, 'Zhongguo Gudai Waike Chengjiu' in Kexueshi Jikan, Beijing, Kexue Chubanshe, 1963, no. 5, p. 8; and also idem, Zhongguo Gudai Yixue Shilue, Shijia Zhuang,
}

Hebei Kexue Jishu Chubanshe, 1990, pp. 114-15; idem, 'Zhongguo Yixue zhi Guanghui', in $\mathbf{L i}$ Jingwen Wenji, Beijing, Zhonggao Zhong Yiyao Chubanshe, 1998, p. 325; and idem, Zhongguo Yixue Tongshi, Beijing, Remming Weisheng Chubanshe, 2000, vol. 1, p. 249.

${ }^{30}$ See Jiang Yanxi et al., Gujin Tushu Jicheng Yibu Quanlu (Collection of ancient and modern books. The Section on Medicine), 'Zonglun Ji Qita', 1725, Beijing, reprinted by Renmin Weisheng Chubanshe, 1963, p. 389. See also Jiang Jizhu et al., Jiangxisheng Guangxinfuzhi, Taibei, Chengwen Chubanshe, 1873, vol. 9, p. 56.

${ }^{31}$ Lü Yanzhao, Yao Nai, Jiangning Fuzhi, vol. 43, 'Jiyi', 1811, p. 5. 


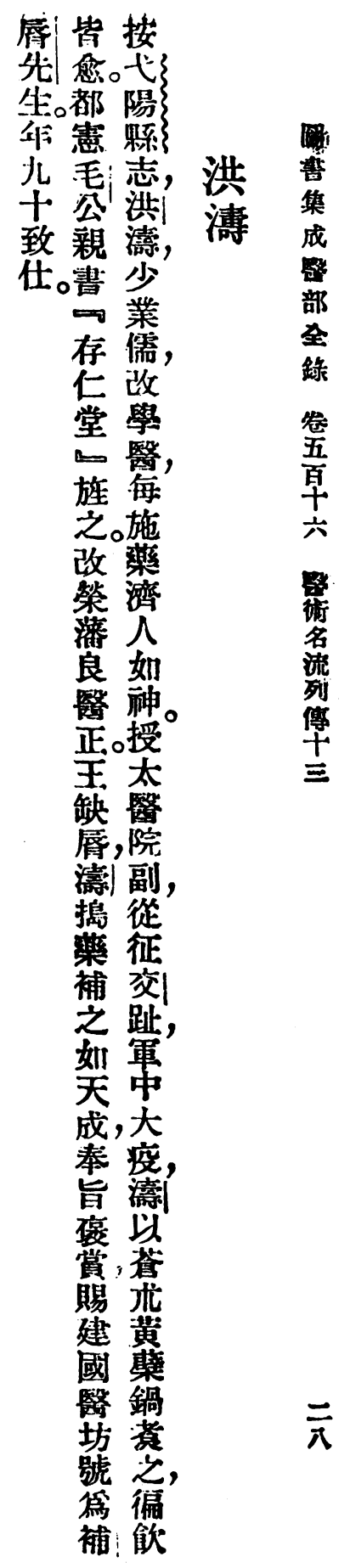

498 


\section{Hare-Lip Surgery in the History of Traditional Chinese Medicine}

stayed for three years in Nantai, Fujian province, during which time he learned to speak Chinese. In 1666, he returned to Japan, and at the age of thirty he came back to China acting as interpreter for a group of Japanese who had come to pay tribute to the Chinese Emperor. One of the members of this group had a hare-lip, which was cured by a Chinese doctor named 黄令友 Huang Huiyou. The cure was so successful that almost no mark of the defect remained. It happened that the grandson of the King of Ryukyu suffered from hare-lip, which made it difficult for him to succeed to the throne. So, again because of his knowledge of Chinese, Tokumei Takamine was sent to China to learn the surgical technique of hare-lip surgery. At first, Huang Huiyou refused to teach him, maintaining that it was a skill handed down from his ancestors. But finally, after repeated requests from Tokumei Takamine, who explained that it was a matter relating to the future of a country, Huang consented. Tokumei Takamine was so absorbed in learning hare-lip surgery under Huang Huiyou's supervision that for twenty days he nearly forgot to eat and sleep, and as a result of this dedication he obtained Huang Huiyou's secret prescription and learned his method of hare-lip operation, which was carried out under general anaesthesia. Returning to Ryukyu on 20 May 1689, he successfully performed the operation on several local people in August. His skill was then recognized and on 11 November of the same year he operated on the grandson of the King of Ryukyu with such success that almost no trace of hare-lip could be seen. He taught the technique to a local doctor named Doko Izashiki (1661-1730), who was also given a secret book on hare-lip operation by Tokumei Takamine. Unfortunately, this book has been lost. Later, in 1714, Tokumei Takamine passed on this skill to two other Japanese doctors. ${ }^{32}$

Although the above accounts of these surgeons are very interesting, no details are given about the surgical procedures and treatment, or of any of the medicines used. Hong Tao was said to have mended Prince Rong Zhuang's hare-lip with medicines, but it is not known whether Ji Renjie used surgery or drugs to rectify the defective lip. As for Huang Huiyou, no reference to his background, methods of surgery and the medicines he used for the general anaesthesia have ever been found in Chinese literature. ${ }^{33}$

Figure 5: (opposite) Brief outline of the life of Hong Tao (fifteenth century) recorded in Yiyang Xianzhi (Annals of the Yiyang county), which mentions that he mended the hare-lip of Prince Rong Zhuang with medicine, and that the mended lip looked like a natural one.

\footnotetext{
${ }^{32}$ See Akitomo Matsuki, 'On Doko Izashiki, Japanese pioneer of anaesthesia at the end of 17th century', Nihon Ishigake Zasch (Journal of the Japan Society of Medical History), 1978, 24 (3): 246-7.

${ }^{33}$ Since I have not been able to find any material about Huang Huiyou, I wrote to Dr
}

\begin{abstract}
Akitomo Matsuki with the hope that he would offer more information. He kindly replied, saying that he would be publishing an article on Huang Huiyou in due course.
\end{abstract}




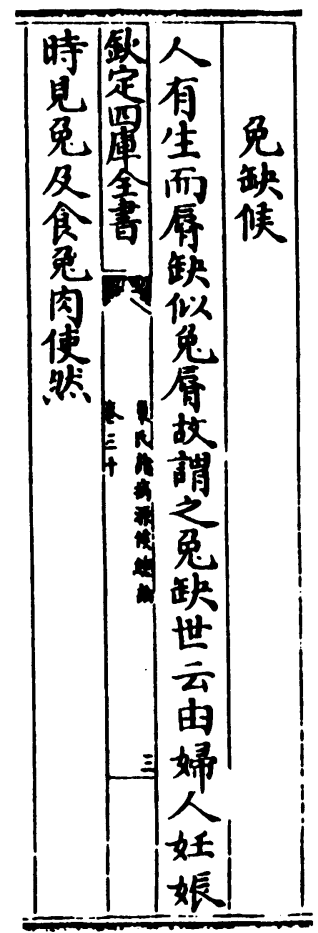

Figure 6: The earliest description of hare-lip in a medical work is found in the Zhubing Yuanhou Zonglun (General treatise of etiology and symptoms and signs of diseases) compiled by Chao Yuanfan et al., in AD 610. It says that it was caused by women seeing hares or eating their flesh during pregnancy (see note 34 ).

\section{Records of Hare-Lip Surgery in Medical Works}

Descriptions of hare-lip and its surgery appeared comparatively late in medical works. The earliest is found in the 諸病源候憾谕 Zhubing Yuanhou Zonglun (General treatise of the etiology and symptoms and signs of diseases) compiled by a group of physicians headed by 桨元方 Chao Yuanfan in AD 610. It says: "Some people are born with a cleft-lip, which looks like a hare's lip, hence its name. It is said that this is due to women seeing hares or eating their flesh during pregnancy"34 (Figure 6). In the section 䏩内十二传 'Taine Shier Zheng' (Twelve illnesses of the fetus) of the 小免街生绕微䄖方 Xiaoer Weisheng Zong Weifang Lun (General treatise of essentials

${ }^{34}$ Chao Yuanfang et al., Zhubing Yuanhou Zonglun, vol. 30, 'Tu Que hou', photomechanical printing, Beijing, Renmin Weisheng Chubanshe, 1955 , p. 158. This work was compiled in AD 610 in 50 volumes, containing 67 categories with
1,720 entries describing the etiology and symptoms of various diseases. It was the first work of its kind in the history of Chinese medicine. 


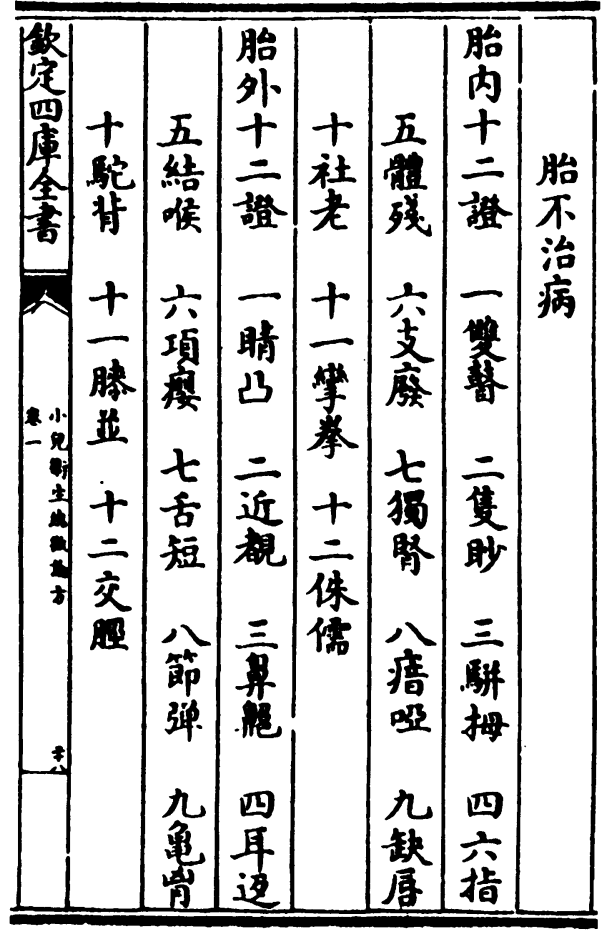

Figure 7: Hare-lip is listed as one of the twelve incurable fetal illnesses in the Xiaoer Weisheng Zong Weifang Lun (General treatise of essentials for the preservation of children) by an unknown author, which appeared in 1156 (see note 35 ).

for the preservation of children), which appeared in 1156, cleft-lip is listed as the ninth of the incurable fetal illnesses ${ }^{35}$ (Figure 7).

Details of the surgical operation for hare-lip or cleft-lip are not recorded in medical literature until the beginning of the seventeenth century when 王肯堂 Wang Kentang compiled his 科被治辈纯 Yangke Zhengzhi Zhunsheng (Standards for diagnosis and treatment of surgical cases) in $1608 .^{36}$ The following passages relate to the operation for cleft-lip caused by trauma and external injury:

\footnotetext{
${ }^{35}$ Xiaoer Weisheng Zong Weifang Lun, photomechanical printing, Beijing, Renmin Weisheng Chubanshe, 1959, p.13. The author of this work is unknown. Fhe book was published by the Imperial Medical Bureau of the Song government in 1156. Its contents were collected from material relating to paediatrics before that time. According to He Daren, commissioner of the Imperial Medical Bureau of the Southern Song dynasty (twelfth to thirteenth centuries), it was originally a book kept by his father, and was later revised by him together with some of his friends and republished in 1216 .
}

\begin{abstract}
${ }^{36}$ Wang Kentang (1549-1613), also called Wang Yutai, a native of Jintan, now in Jiangsu province. A Confucian scholar, he read medical works desultorily when young. Later, he became a successful candidate of the highest imperial examinations in 1589 and was appointed member of the Hanlin Yuan (Imperial Academy), taking responsibility for the compilation of books on history etc. He was demoted for his memorial presented to the Emperor to extirpate the harassment, wrecking, smuggling and other subversive activities of Japanese pirates. In 1592 he resigned by pretending to be ill and returned to his native place, where he devoted himself to
\end{abstract}




\section{Kan-Wen Ma}

For cleft-lip with a gap, first use a 小策针 “Xiao Qi Zhen" (small suture needle) ${ }^{37}$ for a threesection suture. A piece of silk thread whose two ends are fixed with a piece of pig's hair is moistened with saliva. Apply the wound-sealing medicine (powder) to the silk thread, with which a three-section suture is to be carried out. Apply narcotics to the gap of the cleft-lip. Apply wound-sealing powder to the edges of the scissors, with which some of the superficial thin skin is cut off, and suture up the wounded lip. Then apply egg yolk oil ${ }^{38}$ to the wound, and spread some fine hair of Cibot Rhizome (Rhizoma Cibotii) $)^{39}$ on it, and then apply the wound-sealing powder. Wash off the yolk oil lightly once a day with washing medicines. The wound-sealing medicines should be changed only once a day until the eighth day. Then remove the stitches and put medicine on the wound. ${ }^{40}$ (Figure 8.)

Figure 8: (opposite) The first description of the details of the surgical operation to rectify a cleft-lip in a medical work, Yangke Zhengzhi Zhunsheng (Standards for diagnosis and treatment of surgical cases) by Wang Kentang (1549-1613), which appeared in 1608 (see note 36).

the study and practice of medicine. He spent 11 years in the compilation of medical works, collecting ancient and contemporary medical materials. His main achievement was the compilation of the Liuke Zhengzhi Zhungsheng (Standards of diagnosis and treatment of six branches of medicine), which enjoyed great popularity and circulated most widely during the seventeenth century as well as in later periods. The Yangke Zhengzhi Zhunsheng (Standards and diagnosis of surgical diseases) was compiled in 1608. An open-minded man and a prolific writer, apart from his own clinical experiences, his works were comprehensive and included the theories, principles, methods, and prescriptions of different schools and sects in Chinese medicine. He also published many other medical works.

37 "Xiao Qi Zhen", literally means "small airhole needle". No reference so far has been found to it. From the context, it must be a suture needle with a small eye at its root used in defective lip operation.

${ }^{38}$ Egg yolk oil was used in China for head boils from at least the early tenth century $A D$, according to the Rehuazi Bencao (Rehuazi's herbal), whose author was a native of Siming, now Jin county of Zejiang province. The author's surname is unknown. The original book is now lost. Most of its contents were included in other later books. The use of egg yolk oil is recorded in Tang Shenwei's Chungxue Zhenghe Jingshi Zhenglie Beiyong Bencao (Revised classic classified materia medica) AD 1068, revised by Zhang Cunhui in 1249, mechanical photographic printing, Beijing, Renmin Weisheng Chubanshe,
1957, vol. 19, p. 35 . According to a recent clinical observation, the use of egg yolk oil in the treatment of 1.2 degree burns to medium and small areas produced good results without any secondary infections. Pain was relieved and exudation reduced. Scabs were quickly formed and fell off by themselves and usually no scars were left. See Zhongji Yikan, Beijing, 1976, vol. 6, p. 382.

${ }^{39}$ An experimental report of the use of the soft yellow hair of the root and stem of Cibotium barometz (L.) J. Sm., on 22 dogs and 30 rabbits in a total of 118 haemostatic tests showed that it had a positive effect on traumatic bleeding of the liver and spleen. The haemostatic time was quicker than that of other well tried methods and haemostatics, such as hot saline gauze and gelatin sponge. Its powder form produced the best haemostatic effect. It was simpler, more convenient and reliable than the methods of muscular plugging and greater omentum encapsulation. It seemed that the soft yellow hair of the root and stem of Cibotium Saromets was gradually absorbed by the tissues and disappeared. See Zhonghua Waike Zazhi (Chinese Journal of Surgery), report by the Department of Surgery, Pathology, and Laboratory, 1962, 10 (8): 507-9.

${ }^{40}$ Wang Kentang, Yangke Zhengzhi Zhunsheng, 'Fengkou Yao' (Medicines for sealing the wounds), photomechanical printing based on a Ming dynasty edition, Taiwan, Xin Wenfeng Publication Company, 1957, vol. 6, pp. 428, 456-7. 


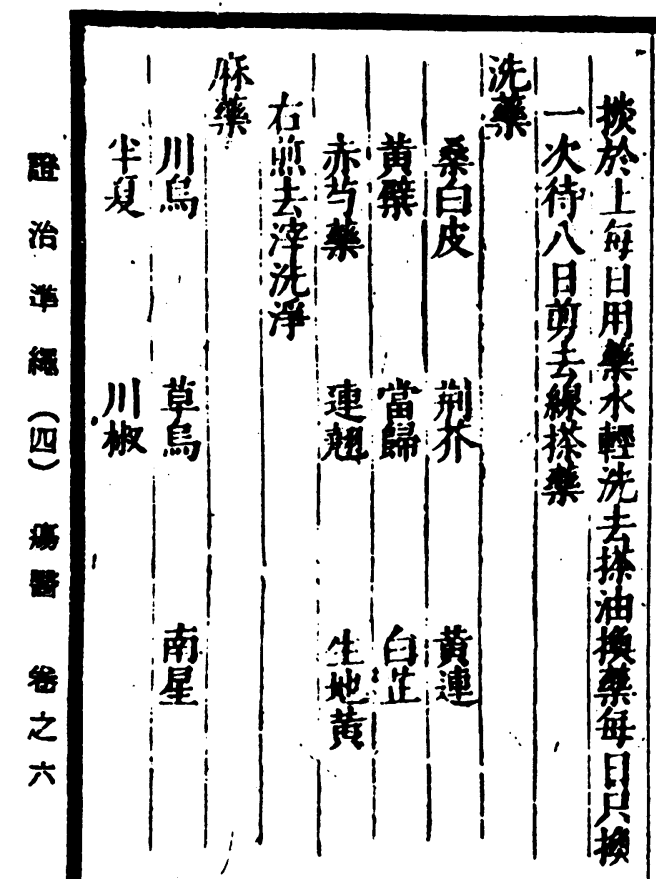

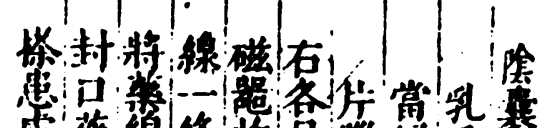

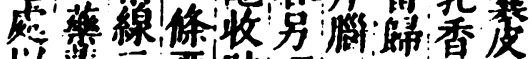

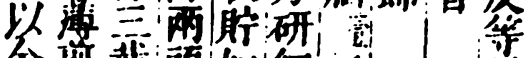

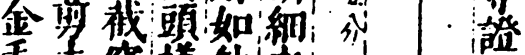

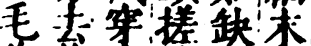

何些定耤虚科

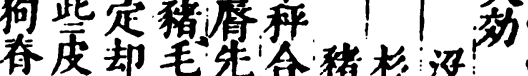

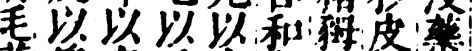

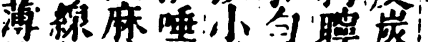

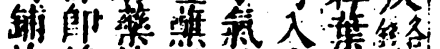

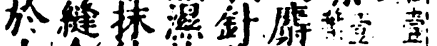

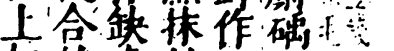

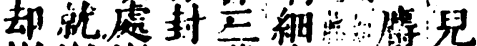

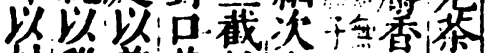

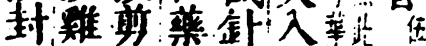

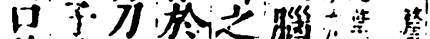

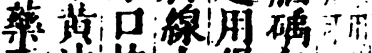

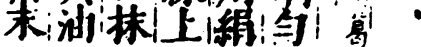

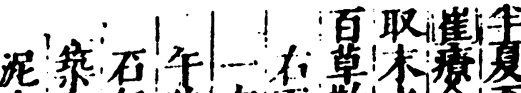

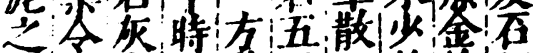

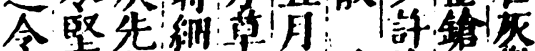

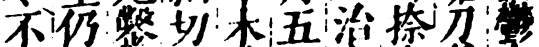

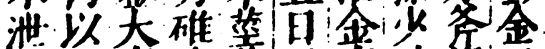

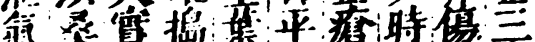

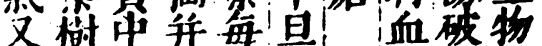
以皮永不程使

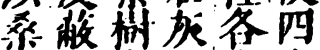

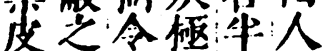
維用订令把出

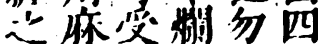

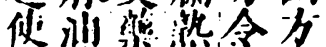

四

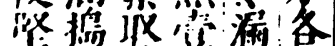

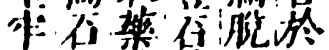

店納管五

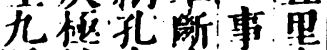

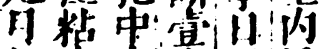

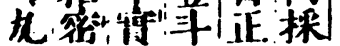

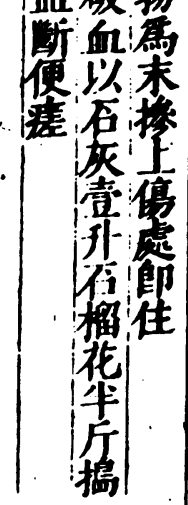

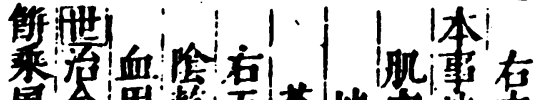

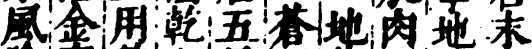

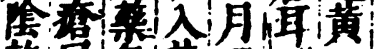

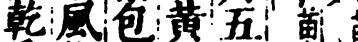
像化封升七! 来石不 傅灰可两七 拝野更目生地

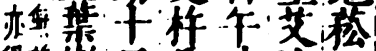

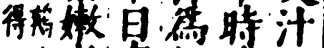
血者疾緗修 间不策

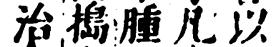

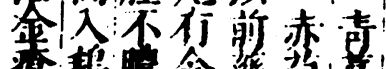

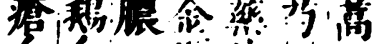
血! 血! 不湔 占:

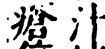

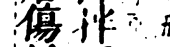
用成! 出放汁讧

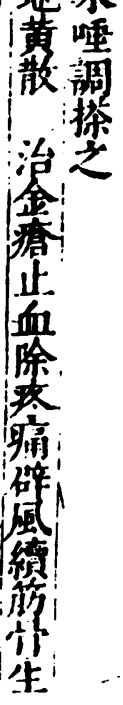




\section{Kan-Wen Ma}

For injuries of the lip or mouth caused by a knife, an axe, or by a fall or graze, which have wounded the skin and flesh, first suture the wound with a suture made of Mulberry bark (Cortex Mori Radicis), then smear wound-sealing medicine (powder) on the wound, and apply a piece of blood-dispersing plaster to cover up the wound and consolidate the wound-sealing medicine so that it will not fall off and the sutured wound will not open again. The patient should be instructed to speak little. For the treatment of a cleft-lip, ear, or nose, caused by a fall, first smear the wound with sealing medicine and then cover it with a piece of blooddispersing plaster. For a cleft-lip or ear, first smear narcotic on it, and then cut off some of the external skin of the lip, and suture it with silk suture. For the cleft ear, use the twosection-suture, and for a cleft-lip with a gap, the three-section-suture method. Then smear the wound with egg yolk oil, and cover it with some hair of Rhizoma Cibotii, and smear it with sealing medicine. On the next day, wash the wound lightly with tea. The wound-sealing medicine should be changed once a day until the eighth day, and the suture trimmed with a pair of scissors . . . for the treatment of an upper cleft-lip with a gap, caused by a knife, an axe, or by a fall, or by graze or knock, the wounded lip should be tied up with a small and narrow strip of silk from behind the occiput to bind it up and suture it, sealing medicine applied, and the wound covered with a piece of blood-dispersing plaster. If the gap is in the lower lip, the wounded lip should be tied up with a piece of silk strip from below the chin, and sutured in the same way as the upper cleft lip. There is no need to apply any medicine to the wound if no swelling occurs. ${ }^{41}$

The composition of the wound-sealing powder is: Frankincense (Olibanum, Resina Olibani) 1 Qian; ${ }^{.2}$ Myrrh (Myrrha, Resina Myrrhae) 1 Qian; Catechu (Acacia catechu, Leguminosae) 1 Qian; Chinese Angelica Root (Radix Angelicae Sinensis) 1 Qian; Charcoal of the bark of Cunninghamia lanceotata (Lamb.) Hook 1 Qian; Musk (Moschus) $5 \mathrm{Li} ;{ }^{43}$ Borneol (Borneolum) 1 Fen; ${ }^{44}$ Leaf of Melas toma candidum D. Don 1 Qian.

The above ingredients should be ground to a fine powder, mixed, and preserved in a porcelain jar. $^{45}$

The ingredients of the washing medicine are: Mulberry Bark (Cortex Mori Radicis); Schizonepeta (Herba Schizonepetae); Coptis Root (Rhizoma Coptidis); Phellodendron Bark (Cortex Phellodendri); Chinese Angelica Root (Radix Angelicae Sinensis); Dahurian Angelica Root (Radix Angelicae Dahuricae); Red Peony Root (Radix Paeoniae Rubra); Forsythia Fruit (Fructus Forsythiae); Rehmannia Root (Radix Rehmanniae).

The above ingredients should be washed clean, decocted and their dregs eliminated. ${ }^{46}$

\footnotetext{
${ }^{41}$ Ibid., vol. 6, p. 429.

42 "Qian", a unit of weight which is equal to 5 grams.

43 " $\mathrm{Li}$ ", a unit of weight which is equal to 0.05 gram.
}

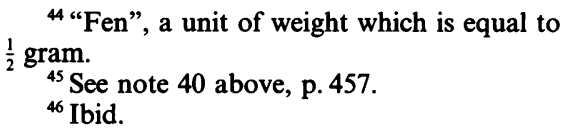




\section{Hare-Lip Surgery in the History of Traditional Chinese Medicine}

The ingredients of the anaesthetic are: Sichuan Aconite Root (Radix Aconiti); Wild Aconite Root (Radix Aconiti Kusnezoffi); Arisaema Tuber, Jack-in-the-Pulpit Tuber (Rhizoma Arisaematis); Pinellia Tuber (Rhizoma Pinelliae); Prickly-ash Peel (Pericarpium Zanthoxyli).

The above ingredients should be mixed well with saliva and then applied to the affected area. ${ }^{47}$

In another work entitled 百化䘫宗 Baidai Yizon (Medicine of a hundred generations), compiled by Tu Shen 涂紟 in 1607, is found a 'Remedy for repairing lip and tongue', as follows:

Take a fresh living $\mathrm{crab}^{48}$ and burn it to ashes. Take two Qian $(10 \mathrm{~g})$ of the ashes and mix it with Frankincense (Olibanum Resina, Olibani) and Myrrh (Resina Myrrhae), two and a half Fen of each $(5.05 \mathrm{~g})$, and smear them on the lip (or on the tongue as well if both the lip and tongue are injured) to promote the growth of the flesh. If the flesh of the lip (or the tongue as well) has been badly torn, put the powder of Sichuan Aconite Root (Radix Aconiti) and Wild Aconite Root (Radix Aconiti Kusnezoffii) mixed with water on a strip of paper and apply it to the wounded area. The patient will thus not feel the pain. Then the knife can be used to carry out the operation. In the case of incessant bleeding, use old lime to smear on the operated area and the bleeding will be stopped immediately. . . ${ }^{49}$

Another work entitled 着量大全 Yangyi Daquan (Complete work of surgery) written by 碩世澄 Gu Shicheng in $1760,{ }^{50}$ contains the following description of the operation for cleft-lip:

\footnotetext{
${ }^{47}$ Ibid.

${ }^{48}$ The use of some parts of the crab, such as the marrow, brain and the ovary and digestive glands, as medicine was recorded in quite a few herbals. For instance, the 本草拾进 Bencao Shiyi (A supplement to the Herbal) by Chen Cangqi in AD 739, says that crab's marrow, brain, and the ovary and digestive glands can be used for severed tendons and fractured bones, and that they should be reduced to pulp and fried over a mild fire, and then applied to boils, ulcers or wounds, as it could assist them to heal up immediately. The original book of the Bencao Shiyi was lost. However, its contents were later included in some other herbals. This item is quoted in Tang Shenwei's Chungxue Zhenghe Jingshi Zhenglie Beiyong Bencao, op. cit., note 38 above, vol. 21, p. 426.

${ }^{49}$ See Tu Shen, Baidai Yizong, wood-block printing, Daye Tang, 1607, p. 15. This book is included in the Zhongyi Guji Guben Daquan
}

(Complete rare works of traditional Chinese medicine), photomechanical printing, Beijing, Zhongyi Guji Chubanshe, 1996, vol. 7, p. 717.

${ }^{50} \mathrm{Gu}$ Shicheng, also called $\mathrm{Gu}$ Cheng, or $\mathrm{Gu}$ Lianjiang, or Gu Jingzhai, was a native of Wuhu county, Anhui province. He later moved to Yangzhou, now in Jiangsu province. Born into a family which had produced three generations of physicians, he practised for over forty years, and was particularly well-known for his treatment of external diseases. He maintained that to treat external diseases successfully one should also be knowledgeable in internal medicine. As he thought that most medical works of the period were chiefly concerned with internal medicine, he spent many years collecting reliable methods both ancient and current, together with material from his grandfather, father and his personal experiences, and compiled in 1760 the Yangyi Daiquan (Complete work of surgery) in $\mathbf{4 0}$ volumes, which was published in 1773. 


\section{Kan-Wen Ma}

Take a piece of child's bone ${ }^{51}$ and put it into an earthenware bowl to calcine it with bran-fire. Then grind it into extremely fine powder; only 1 Fen $(1 / 2 \mathrm{~g})$ is to be used. Take rosin (5 Fen in extremely fine powder form); fine hair of Rhizoma Cibotii, which should be baked on a piece of clay tile and ground into a fine powder; only 1 Qian $(5 \mathrm{~g})$ is to be used. Elephant skin 1 Qian $(5 \mathrm{~g})$, which should first be pounded until soft, soaked with hot spirits, baked on a piece of clay tile and then ground into a fine powder; alumen 3 Fen $(1.5 \mathrm{~g})$ in fine powder.

First, apply the narcotic to the cleft-lip, then puncture the skin of the gap of the lip with a small sharp knife to cause it to bleed, and retain the blood in a porcelain plate. Then mix the blood with the above prepared medicines, and fix the skin of the two sides of the gap of the lip with an embroidery needle threaded with silk, and then apply the medicine prepared with the blood. No weeping and laughing are allowed for three to five days. Avoid exposure to wind and sneezing. Only thin porridge is allowed for the daily meal until the flesh of the lip has fully grown. Then the silk suture can be removed and the cleft-lip will be mended. ${ }^{52}$ (Figure 9.)

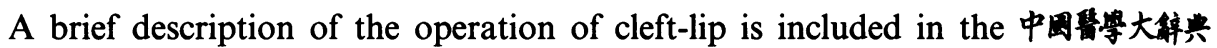
Zhongguo Yixue Dacidian (Comprehensive dictionary of Chinese medicine), published in 1921:

For the treatment of cleft-lip with a gap, it is feasible to cover it with narcotics, then cut open the thin skin of its two sides, and suture them up with silk suture. Then cover the wound with crab's ovary and digestive glands. The patient should sit quietly without speaking and smiling for seven days, and the wound will be healed. Or, apply a medicinal pill made of Dragon's bone (Os Draconis) $)^{53}$ and white wax (insect wax) to the cleft-lip, and suture it with an embroidery needle. ${ }^{54}$

Unfortunately, no reference source for this description is given in this dictionary.

Figure 9: (opposite) Description of the procedures for the operation for hare-lip in the Yangyi Daquan (Complete work of surgery) written by Gu Shicheng in 1760 (see note 52).

\footnotetext{
${ }^{51}$ The use of the bone of a dead child for treating traumatic wounds was recorded in Becao Gangmu (Compendium of materia medica) (1590) by Li Shizhen (1518-1593), and in Bencao Gangmu Shiyi (A supplement to the compendium of materia media) (1765) by Zhao Xuemin. A piece of bone of a dead child was first burned directly or indirectly in a container to make it loose and brittle, then mixed with seeds of muskmelon which had been fried dry and ground into powder. The patient drank the concoction with wine. It was said that pain would soon be relieved. However, Li Shizhen, with a Confucian point of view, dissented from the use of it, saying that some healers used human bone to make
}

profit. See Bencao Gangmu, reprint, Beijing, Renmin Weishen Chubanshe, 1981, vol. 4, p. 2960.

${ }^{52} \mathrm{Gu}$ Shicheng, Yangyi Daquan, reprint, Shanghai, Tushu Jicheng Yinshu Ju, 1901, vol. 14 'Chun Kou Bu', p. 47.

${ }^{53}$ Dragon's bone (Os Draconis) consists of the fossil bone of ancient large mammals, such as Stegodon orientalis and Rhinocerus sinensis. In China, to protect palaeontological remains, its use as a drug is now forbidden, and Oyster Shell (Concha Ostreae) is suggested to take its place.

${ }^{54}$ Xie Guan, Zhongguo Yixue Dacidian, Shanghai, Commercial Press, 1921, p. 2300. 


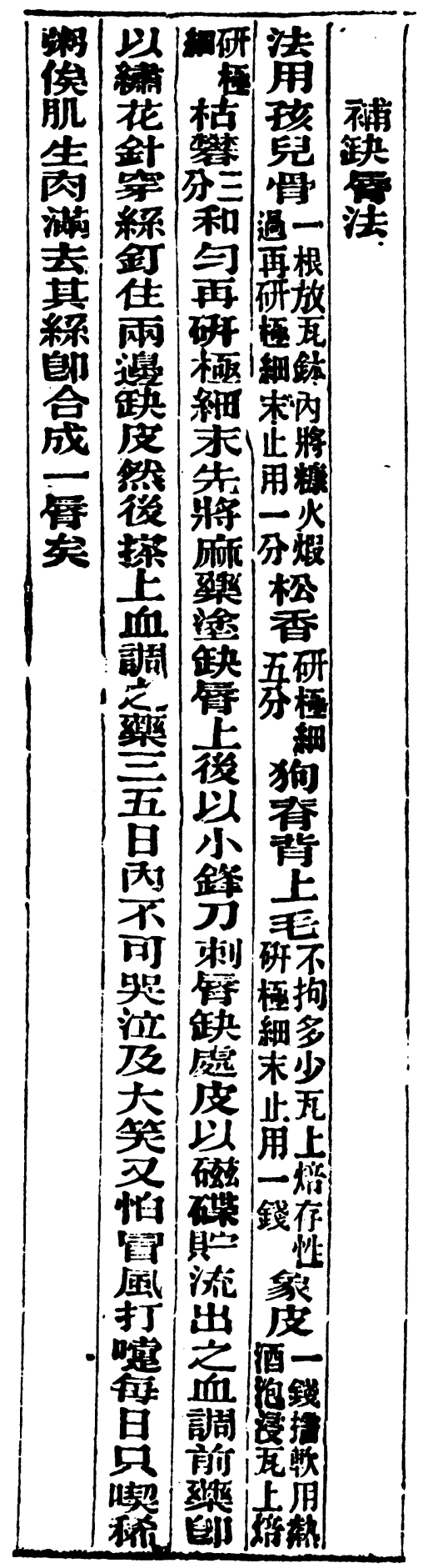




\section{Kan-Wen Ma}

It is interesting to see that most of the medicines used for the operation have been proved by modern pharmacological and clinical studies to have either antiseptic and anti-inflammatory properties or to be useful in alleviating pain. ${ }^{55}$

The sutures used in the cleft-lip operations are recorded in the earlier periods in a surgical context. At least as early as the third century AD, sutures made of Mulberry bark (Cortex Mori Radicis) were used in the operation of trauma. ${ }^{56}$ In $\mathrm{AD} 693$, a court physician used this kind of suture in an operation on a court worker who cut

\footnotetext{
${ }^{55} 215$ cases of cervical erosion treated with pills prepared chiefly with Frankincense (Olibanum), 92 were healed (43 per cent), 96 cases registered improvement (45 per cent), and 27 (12 per cent) showed no change. It was also proved that this drug had a stronger bacteriostatic effect than various kinds of antibiotics; see Department of Gynaecology and Obstetrics, the First Hospital of the Beijing Medical College, 'Zigongwan Zhiliao Gonging Milan Linchuang Guancha $\mathrm{He}$ Yanjiu' (Clinical observation and research on using Zigong Wan in the treatment of cervical erosion), in Beijing Yixueyuan Xuebao (Bulletin of Beijing Medical College), 1959, no. 1: 17-21; Radix Paeoniae Rubra in vitro was found to be of strong antibacterial on seven Gram-negative bacterium, including Bacillus dysenteriae, Typhoid bacillus, Bacillus paratyphosus, Vibrio comma, Bacillus coli, Bacillus proteus, and Pseudomonas aeruginosa (see Liu Guosheng, 'Research on the antibacterial function of Chinese herbs', in Zhonghua Xinyi Xuebao (Bulletin of Chinese New Medicine), 1950, no. 1: 95-7), and on five Grampositive bacterium, including Staphylococcus, ahemolytic streptococcus, B-streptococcus, Pneumococci, and Bordetella pertussis. Decoction of Radix Angelicae Sinensis in vitro was reported to be antibacterial on various bacteria, including Bacillus dysenteriae, Bacillus paratyphosus, Vibrio cholerae, Bacillus coli, Bacillus proteus, ahemolytic streptococcus, and Bacillus diphtheriae, see Liu Guosheng, ibid., 1950, no. 2: 285-7. Achromic needle-shaped crystals extracted from Radix Rehmanniae with alcohol were reported to have the effect of promoting hemopexis, see Angua Changnan, 'Influence of various folk herbs on hemopexis', in Yixue Zhongyang Zazhi, Japan, 1941, no. 69: 668 (see also Liu Shousan, Zhongyao Yanjiu Wenxian Zhaiyao (Abstracts of research on Chinese herbs), Beijing, Kexue Chubanshe, 1975, p. 207). Rhizoma Coptidis was used in 100 cases of acute suppurative traumatic wound infection, and proved to be more effective
}

than vaseline gauze, and of an extensive bacteriostatic pedigree, see Li Jitang, 'Huanlian Yingyongzhai Huanuxing Chuangkou Jiqidui Huanujun di Kuangjun Shiyan' (Experiment of the antibacterial effect of Rhizoma Coptis on suppurative traumatic wounds and pyogenic bacterium), in Zhonghua Waike Zaizhi (Chinese Journal of Surgery), 1958, no. 7: 749-52. Good results were obtained by using ribbon gauze prepared chiefly with Cortex Phellodendri decoction to substitute for rivanol in the treatment of surgical conditions, see Ye Naihan, 'Huangbaiye Kedaiti Renoval Yingyongyu Waike Jihuan' (Application of Cortex Phellodendri decoction to surgery as a substitute for rinoval), in Zejiang Zhongyi Zaizhi (Zejiang Journal of Chinese Medicine), 1960, no. 3: 140. Sichuan Aconite Root was found experimentally to be analgesic, see Xian Yixueyuan Yaoli Jiaoyanshi Xueshen Keyan Xaiojuo, 'Chuanwutou Zhenjing Zhueyong Shiyan Yanjiu' (Experimental study of the analgetic effect of Sichuan Aconite), in Xian Yixueyuan Xuebao (Bulletin of the Shanxi Medical College), 1967, no. 4: 32-7. Volatile oil of Chinese Prickly-ash peel (Pericarpium Zanthoxyli) was used for oral mucous anaesthesia in 100 patients, 84 of whom felt no pain, 13 felt some pain during the operation, only 3 felt much pain and the operation was not carried out, see Xia Poyang, 'Huajiao Huifayou Kouchang Nianmo Majui Baya Yibaili' (Application of Volatile oil of Chinese Prickly-ash peel to oral mucous anaesthesia, a report of 100 cases), in Zhongguo Yiyuan Yaoxue Zaizzhi (Journal of Pharmacology of the Zhongguo Hospital), 1983, 3 (9): 38

${ }_{56}$ Mulberry bark suture used in the treatment of traumatic wounds was recorded in Mingyi Bielu (Transactions of famous physicians), a book on herbs and drugs compiled by an unknown author probably in the third century $\mathrm{AD}$, and later re-edited by Tao Hongjing (452-536), a noted Daoist who specialized in the study of 


\section{Hare-Lip Surgery in the History of Traditional Chinese Medicine}

open his own belly, which resulted in the protrusion of his internal organs. ${ }^{57}$ 危亦林 Wei Yilin (1277-1347), a noted expert in the treatment of external diseases, in his book 世售得效方 Shiyi Dexiao Fang (Effective remedies tested by physicians for generations) compiled in 1345, also recommended the use of Mulberry bark thread suture in the operation of abdominal trauma. ${ }^{58}$ This suture was still being used for the treatment of traumatic wounds by the army of the Taiping Heavenly Kingdom during their war against the Qing government between the years 1847 and 1868. An interesting point is that there was no need to remove the stitches when the wound was healed, for the suture could be absorbed by the tissues of the treated area ${ }^{59} \mathrm{~A}$ recent preliminary experimental study on the use of this suture for trauma on dogs showed the similar result. ${ }^{60}$

\section{Discussion}

Was it really possible to perform hare-lip operations at such an early period in China as recorded in the Jin Shu?

herbs. This work is now lost, but most of its contents were collected in the Tang Xinxuo Bencao (Newly compiled materia medica of the Tang dynasty), the earliest known pharmacopoeia issued by a government, which was completed by $\mathrm{Su}$ Jing with 22 other scholars under the auspices of the Tang government in the year 659. It consists of 54 volumes and described 850 different drugs and was widely quoted in many later herbals. So although the original copy is lost, its contents can still be seen in many herbal works. The description of the use of Mulberry bark thread suture for traumatic wounds is seen in its reedited and annotated edition by Shang Zhijun, published in Anhui by Kexue Jishu Chubanshe, 1981 , p. 335. It is also seen in Tang Shenwei, op. cit., note 38 above, vol. 13, p. 315 .

${ }^{57}$ Ouyang $\mathrm{Xu}$ et al., Xin Tang Shu (New annals of the Tang dynasty) 1060 , Shanghai, reprinted by Zhonghua Shuju, 1975, vol. 191, 'Lie Zhuan 116', p. 5506. According to this book, in the second year (693) of Chang Shou (692-694) during the reign of the Empress Dowager Wu Zetian, a report reached the Express Dowager that her son, the dethroned Emperor Rui, was conspiring against her. To verify the accusation, she ordered a man called Lai Junchen, who was loyal to her, to interrogate the close attendants of the dethroned Emperor with cruel torture. A worker at the court called An Jinzang cut open his own belly to prove the truth of his assurance that there was no such conspiracy against the
Empress Dowager. His intestines protruded from his abdomen with severe haemorrhaging. He was treated by a court physician who replaced his intestines in his abdomen and sutured the wound with Mulberry bark thread. The next day he returned to consciousness. This story is also reported in Zizhi Tongjian (Synopsis of history) by Sima Qian in 1084, reprinted by Shanghai Guji Chubanshe, 1987, vol. 205, 'Tang Ji 21', p. 1382. See also Tang Shenwei, op. cit., note 38 above, vol. 13, p. 315 .

${ }^{58}$ Wei Yilin, Shiyi Dexiao Fang, 1345, in Siku Quanshu, 'Zibu', mechanical photographical printing, Shanghai, Guji Chubanshe, 1987, vol. 18 , p. 6.

${ }^{59}$ See Geng Jianting, 'Cong Liuzhi Jiegu Lianxiangdao Sangpixian Fengshang' (An association of the reduction of fracture with the treatment of traumatic wounds by Mulberry bark thread suture), Jiangsu Zhongyi (Jiangsu Journal of Chinese Medicine), 1958, (10): 28. The author also gives information about the method of making the Mulberry bark thread suture.

${ }^{60}$ Chen Xinmin et al., 'Sanbaipisan Fenghe Chuangshang di Shiyan Xiaojie' (Experimental research on the Mulberry bark suture in the treatment of traumatic wounds), Wuhan Zhongyi (Wuhan Journal of Chinese Medicine), the first issue, 1968, p. 68. The authors remarked that a small part of the suture was not absorbed. This was probably due to the thickness of the suture, which was made by hand and uneven. 
The long history of surgery in China suggests that this is highly likely. In the Zhou $L i$ (The rituals of the Zhou dynasty), a work recording the Zhou dynasty's political, economic and social systems, probably compiled during the period of the Warring States (475-221 BC), one of the four categories of medical practitioners attached to the Court was the 瘏 “Yang Yi", who were surgeons treating external illnesses, such as swellings, ulcers, wounds and injuries, fractures, etc. ${ }^{61}$

A surgical work entitled 金邻方 Jinchuang Qizong Fang (Remedies for injuries and convulsions caused by metal weapons) was the earliest known work of its kind in ancient China. It was mentioned in the Hanshu Yiwen Zhi (Records of arts and literature of the Han dynasty), ${ }^{62}$ which was compiled in the first century AD, so it must have appeared during that century or earlier. Although it has long been lost, many references show that by the time of the Han dynasty (206 BC-AD 220) there were practitioners specializing in the treatment of various kinds of surgical problems. Among the known surgical practitioners was 位 Hua Tuo (AD 141-203?) whose biography is recorded in Sanguo Zhi (History of the Three Kingdoms) by Chen Shou (AD 233-297) and Hou Han Shu (History of the Late Han dynasty) by Fang Ye (AD 398-445). Apart from acupuncture and herbal medicine, Hua Tuo was also celebrated for his skill in surgery. He was said to have carried out abdominal operations and to have used anaesthesia. ${ }^{63}$ The Jin dynasty (265-420) saw many developments in surgery, especially in military surgery because of frequent wars. The standard surgical procedures of the era are found in 消毛兔方 Liu Juanzi Guiyi Fang (Liu Juanzi's remedies left over by ghosts) written by Liu Juanzi in the early fifth century AD and later edited by 責哾宣 Gong Qingxuan between 496 and 499. This is the earliest surviving work to deal exclusively with surgery in China. The wording of the title indicated perhaps that its contents were miraculous thus rendering it more popular. It was fundamentally an accumulation of the surgical experiences of the author during his service as a surgeon in the army. It deals mainly with the treatment of traumatic wounds, carbuncles, mastitis, burns and skin diseases, with notes on surgery, nursing, drainage and sterilization, etc. It is clear that by this period considerable surgical skills had developed. This supports the argument for the successful performance of hare-lip surgery during the time of Wei Yongzhi recorded in the annals of the Jin dynasty.

Why is there no record in the accounts of Wei Yongzhi and Fang Gan of the names of the two surgeons or of the procedure of their operations?

This was chiefly because first, the surgeons who carried out the operations were not the main protagonists of these stories, and it was only because well-known historical figures like Wei Yongzhi and Fang Gan suffered from hare-lip that their

\footnotetext{
${ }^{61}$ See Zhou $L i$, vol. 1, 'Tian Guan Zhongzai' 1, pp. 3-4, in Qinding Siku Quanshu, mechanical photographic printing, Shanghai, Commercial Press, 1936.

${ }^{62}$ Ban Gu, Han Shu, 'Yiwen Ji', Beijing, reprinted by Zhonghua Shuju, 1962, vol. 30, p. 1778.

${ }^{63}$ Chen Shou, Sanguo Zhi, Beijing, Zhonghua Shuju, 1959, vol. 29, 'Wei Shu', 'Fangji Zhuan',
}

pp. 799-803; see also Fan Ye, Houhan Shu, Hong Kong, Zhonghua Shuju, 1971, vol. 82, 'Hua Tuo Zhuan', pp. 2736-40. By the time of Hua Tuo, some herbs which had anaesthetic properties, such as Aconite Root (Radix Aconiti), Henbane seed (Semen Hyoscyami), etc., might have been used in surgical operations. 


\section{Hare-Lip Surgery in the History of Traditional Chinese Medicine}

treatment was recorded. That is to say, the hare-lip treatment was mentioned only incidentally, just as the phenomenon of disfigurement caused by smallpox was not described until some nobles suffered from it. Secondly, surgeons' social position was low and surgical skill was not highly regarded. As in the West, so in China, surgeons were considered inferior to physicians. Surgeons chiefly dealt with external illnesses, including carbuncles, ulcers, skin diseases, wounds, etc. Frequently surgery was practised by illiterates who were unable to record their experiences and techniques. They were looked down upon by physicians, who were usually men of letters and versed in medical theories and principles and able to deal with internal diseases of more obscure causes as well as external disorders.

But why then are the names of Hong Tao and Ji Renjie mentioned? This was chiefly because annals in China traditionally include the names of persons and events that were considered significant to that area. Hong Tao was a court physician and had been attached to the Prince Rong Zhuang, Zhu Youshu, while Ji Renjie was the grandson of a noted local doctor who had been a court physician, and was himself well-known for his surgical skill.

The method of hare-lip operation appeared so late in medical works for several reasons. First, as mentioned, surgeons were often illiterate, and were not able to record their techniques. Second, surgical procedures and related remedies were kept as a personal or family secret which was generally not disclosed except to the surgeon's own family and trusted pupils. This secret knowledge was even forbidden to daughters, who left home upon marriage, and it was also forbidden to write down such knowledge. Besides, in ancient China, books were written by hand in very brief notes on silk, wood or bamboo strips. It was only after improvements in paper making, and especially following the improvement of printing methods that more medical works were written and circulated more widely.

From the fourteenth century a new trend advocated by eminent physicians emphasized that surgical problems should be considered in combination with the internal condition of the patient, and that surgeons should therefore be competent in internal medicine. Many physicians and surgeons became competent in both internal and surgical medicine. Thanks to a man like Wang Kentang, an openminded physician and prolific writer, some of the details of the operation of defective lip have been recorded.

It can be assumed that in China in the past there may have been many different methods of treatment for hare-lip or cleft-lip carried out by anonymous practitioners that were not recorded. Some ways of treating hare-lip appear bizarre. For instance, a missionary doctor in China reported in $\mathbf{1 8 9 2}$ that hare-lip was sometimes treated by creating a granulated surface with an escharotic, and then bringing together the granulated edges by side pressure. ${ }^{64}$

\footnotetext{
${ }^{64}$ John C Thomson, 'Surgery in China', The China Missionary Journal, 1892, 6 (4): 227.
} 


\section{Kan-Wen Ma \\ Conclusions}

The earliest record in China of someone born with a cleft-lip 铁脣 (Que Chun) with its cause relating to the hare or rabbit in China is found in the Huainan $\mathrm{Zi}$, a non-medical book attributed to Liu An (179-122 BC).

The first use of the term 兔铁 "Tu Que" (hare-lip) and the first record of its successful operation are found in the Jin Shu, also a non-medical work. The operation was carried out between AD 392 and 395.

The first description of hare-lip in Chinese medical literature is recorded in Zhubing Yuanhou Zonglun compiled in AD 610.

The first detailed description of surgical treatment for cleft-lip caused by trauma is found in Wang Kentang's Yangke Zhengzhi Zhunsheng, published in 1608.

The Chinese records of the treatment of hare-lip and defective lip are not only of historical significance, the methods and in particular the medicines used are perhaps of some practical value and merit further investigation. 